\title{
Some Novel Manganese(III) Mixed Ligand Complexes and Its Decolourization Studies
}

\author{
DEEPIKA JAISWAL and SUDHA YADAVA* \\ Department of Chemistry, D. D. U. Gorakhpur University, Gorakhpur, U.P, India. \\ ${ }^{*}$ Corresponding author E-mail: dr_sudhayadava@ yahoo.co.in \\ http://dx.doi.org/10.13005/ojc/340625
}

(Received: August 17, 2018; Accepted: November 03, 2018)

\begin{abstract}
Some novel mixed ligand complexes of $\mathrm{Mn}(\mathrm{III})$ with glycine ligand namely [Mn(gly $\left.)_{2} \mathrm{Cl}(\mathrm{en})\right]$, [Mn(gly) $\mathrm{Br}(\mathrm{en})],\left[\mathrm{Mn}(\mathrm{gly})_{2} \mathrm{~N}_{3}(\mathrm{en})\right]$ and [Mn(gly) $\left.\mathrm{NCS}(\mathrm{en})\right]$ have been synthesized starting from $\mathrm{Mn}(\mathrm{gly}){ }_{2} \mathrm{Cl}, \mathrm{Mn}(\mathrm{gly}){ }_{2} \mathrm{Br}, \mathrm{Mn}(\mathrm{gly}) \mathrm{N}_{2} \mathrm{~N}_{3}$ and $\mathrm{Mn}(\mathrm{gly})_{2} \mathrm{NCS}$ respectively. These newly synthesized complexes have been characterized by UV-Vis, FT-IR and Mass spectrometry. The spectroscopic data suggest distorted octahedral geometry for all these mixed ligand complexes. The $\lambda$ max values of these complexes for ${ }^{5} \mathrm{~T}_{2 \mathrm{~g}} \rightarrow{ }^{5} \mathrm{Eg}$ transitions are $482 \mathrm{~nm}$ for [Mn(gly) $\left.{ }_{2} \mathrm{~N}_{3}(\mathrm{en})\right], 488$ for [Mn(gly) $\left.{ }_{2} \mathrm{NCS}(\mathrm{en})\right], 486$ for $\left[\mathrm{Mn}(\mathrm{gly})_{2} \mathrm{Br}(\mathrm{en})\right]$ and 484 for $\left[\mathrm{Mn}(\mathrm{gly})_{2} \mathrm{Cl}(\mathrm{en})\right]$, all these transitions are red shifted in comparison to their parent complexes. The ligand field parameters such as $10 \mathrm{Dq}, \mathrm{B}$ and $\beta$ have also been calculated and suggest covalent metal ligand bonding. One peculiar finding is that the FT-IR spectra shows frequencies for both free and coordinated $\mathrm{NH}_{2}$ group in all complexes indicating that the ethylenediamine ligand present here is non bridging in nature. The mass spectrometry results show molecular ion peaks at $\mathrm{m} / \mathrm{z} 300,345,307$ and 323 for [Mn(gly) $\left.{ }_{2} \mathrm{Cl}(\mathrm{en})\right]$, [Mn(gly) $\left.{ }_{2} \mathrm{Br}(\mathrm{en})\right]$, $\left[\mathrm{Mn}(\mathrm{gly})_{2} \mathrm{~N}_{3}(\mathrm{en})\right]$ and [Mn(gly) $\left.{ }_{2} \mathrm{NCS}(\mathrm{en})\right]$ respectively. The coordination of ethylenediamine to $\mathrm{Mn}$ (III) enhances its efficiency towards decolourization methyl red dye.
\end{abstract}

Keywords: Mn(III) mixed ligand complexes, Glycine, Ethylenediamine, Dye decolourization.

\section{INTRODUCTION}

Synthesis, characterization, and applications of $\mathrm{Mn}$ (III) complexes had been the focus of global research interest due to their role in the chemical and biological system ${ }^{1-7}$. Mn(III) complexes supported on $\mathrm{Fe}_{3} \mathrm{O}_{4}$ nanoparticles had been used for selective oxidation of thiols to sulphides ${ }^{8}$. Mn(III) porphyrin anchored onto multiwall carbon nanotubes had been used as an efficient and reusable catalyst for heterogeneous reduction of aldehyde and ketones ${ }^{9}$. $\mathrm{Mn}$ (III)-Schiff base dicyanamide complexes had been used for checking the rhombicity effect in peroxidase studies $^{10}$. The application of encapsulated Salen- and
Salhd-Mn(III) complexes in an AP- pillared clay for bicarbonate assisted epoxidation of cyclohexane had been demonstrated ${ }^{11}$. $\mathrm{Mn}$ (III) had been found to play an important role at the redox centers of biological systems, important among those are $\mathrm{Mn}$ containing catalase, $\mathrm{Mn}$ containing ribonucleotide reductase, and the oxygen evolving center of photosystem II (PS-II) ${ }^{12}$. Attempts had been made to mimic the active site of these enzymes also ${ }^{13-15}$. In most of the cases, $\mathrm{Mn}$ (III) complexes have been synthesized using potassium permanganate or $\mathrm{Mn}$ (II) and $\mathrm{Mn}$ (III) acetate ${ }^{16-19}$. However, most of the reported $\mathrm{Mn}$ (III)-complexes have octahedral or square pyramidal geometry ${ }^{15,20-21}$.

This is an Open Access article licensed under a Creative Commons license: Attribution 4.0 International (CC- BY). Published by Oriental Scientific Publishing Company @ 2018 
The above studies prompted the authors' group to initiate the studies on the synthesis, characterization and application of $\mathrm{Mn}$ (III) complexes. In an earlier study, synthesis and characterization of novel complexes of $\mathrm{Mn}$ (III) with macrocyclic porphyrin ligand and ethylenediamine have been reported by this group ${ }^{22}$. The depolymerization activity of these complexes towards humic acid as coal model had also been reported earlier ${ }^{23}$. Recently Mn(III)-porphyrin complexes with oxidation property have been reported by our group ${ }^{24}$. Another work on synthesis and characterization of a novel $\mathrm{Mn}(\mathrm{III})$-( $\gamma$-diketone) complex with catalytic and antifungal activity have also been reported from our laboratory ${ }^{25}$. Tris(glycinato) Mn(III) complex has been synthesize for the first time in our laboratory ${ }^{26}$. There is a report in the literature ${ }^{27}$ that coordination of imidazole to $\mathrm{Mn}$ (III) in a Mn(III)-porphyrin complex enhances the catalytic activity of the complex towards the oxidation of benzyl alcohol to benzaldehyde in presence of sodium periodate. Considering the above report, the authors have synthesized and characterized ethylenediamine mixed ligand complexes of $\mathrm{Mn}^{(\mathrm{III})}(\mathrm{gly})_{2} \mathrm{Cl}, \mathrm{Mn}^{\text {(III) }}(\mathrm{gly})_{2} \mathrm{Br}, \mathrm{Mn}^{\text {(III) }}$ (gly) ${ }_{2} \mathrm{NCS}$, and $\mathrm{Mn}^{(\mathrm{III})}(\mathrm{gly})_{2} \mathrm{~N}_{3}$ and have studied the decolourization potential of these novel complexes towards decolourization of methyl red dye. It has been observed that substitution of ethylenediamine in $\mathrm{Mn}(\mathrm{gly})_{2} \mathrm{X}$ complex enhances its efficiency as a heterogeneous catalyst towards the decolourization of Methyl Red in presence of $\mathrm{H}_{2} \mathrm{O}_{2}$.

\section{MATERIALS AND METHODS}

Glycine was purchased from Mumbai (sigma-aldrich). All the reagents and solvents were of analytical grade and procured from Merck Ltd., Mumbai (India) and used without further purification. Mill-Q water had been used throughout the experiments.

\section{Characterization}

The purity of these complexes was checked in our laboratory by TLC method using Silica gel on glass plates. The mobile phase was dichloromethane and methanol 7:3 (v/v). Detection was made by keeping the TLC glass plates in iodine-chamber. The complexes were analyzed for $\mathrm{C}, \mathrm{H}$, and $\mathrm{N}$ element in Sophisticated Instrumentation Center of Cochin University of Science and Technology, Cochin. The UV-Vis spectra of the complexes were recorded on UV-Vis Spectrophotometer Hitachi (Japan) model U-2900 available in our laboratory. The FT-IR spectra of the complex were recorded on Perkin Elmer FT-IR spectrometer 2000 in KBr disk at the Indian Institute of Technology Kanpur. Magnetic susceptibility measurement data for all these Mn (III) complexes were recorded by the instrument VSM (vibrating sample magnetometer) at IIT Kanpur. DART mass spectra of complexes were recorded on Reservoir, JMS-T100LC at the Sophisticated Analytical Instrumentation Facility, Central Drug Research Institute, Lucknow.

\section{Synthesis \\ Preparation of ethylenediamine complexes, $\left[\mathrm{Mn}(\mathrm{gly})_{2} \mathrm{X}(\mathrm{en})\right]$}

All these $\left[\mathrm{Mn}(\mathrm{gly})_{2} \mathrm{X}(\mathrm{en})\right]$ complexes were prepared according to the earlier reported procedure in the literature ${ }^{26,28}$ where $\mathrm{X}=\mathrm{Cl}^{-}, \mathrm{Br}^{-}, \mathrm{N}_{3}{ }^{-}, \mathrm{NCS}^{-}$.

For the preparation of azido complex, $0.82 \mathrm{~g} \mathrm{Mn}(\mathrm{gly}){ }_{2} \mathrm{~N}_{3}$ complex was refluxed with $1 \mathrm{~mL}$ of ethylenediamine for 18 hours. After refluxion the obtained product was cooled for $1 \mathrm{~h}$ at room temperature $\left(27^{\circ} \mathrm{C}\right)$ resulting in dark black powder of $\mathrm{Mn}(\mathrm{gly})_{2} \mathrm{X}$ (en) complex, which was dried under vacuum over $\mathrm{P}_{2} \mathrm{O}_{5}$ and washed with mill $\mathrm{Q}$ water. The $\mathrm{Cl}^{-}, \mathrm{Br}$ and $\mathrm{NCS}^{-}$ethylenediamine complexes were prepared analogously.

The reaction scheme for all these synthesized complexes is given below.

$\left[\mathrm{Mn}(\mathrm{gly})_{2} \mathrm{X}\right]+$ en $\underset{18 \text { hrs. }}{\stackrel{\text { Reflux }}{\longrightarrow}}\left[\mathrm{Mn}(\mathrm{gly})_{2} \mathrm{X}(\mathrm{en})\right]$

Where gly = glycine, $\mathrm{X}=\mathrm{Cl}^{-}, \mathrm{Br}^{-}, \mathrm{NCS}^{-}$and $\mathrm{N}_{3}^{-}$

\section{Catalysis of methyl red by the complexes}

The reaction solution $(2 \mathrm{ml})$ consisted of $0.24 \%$ methyl red, $14.63 \% \mathrm{H}_{2} \mathrm{O}_{2}$ and $0.5 \mathrm{mg}$ of the complex in milliQ water Since the complexes were insoluble in the reaction medium hence acted as heterogeneous catalysts. The time of $100 \%$ decolourization of the dye was recorded with the help of a stopwatch by visual observations. The UV/Vis spectra of the reaction solution before and after the decolourization of dye was recorded.

\section{RESULTS AND DISCUSSION}

The objective of this communication has been clearly stated in the introduction section. Here ethylenediamine added complexes of $\mathrm{Mn}(\mathrm{gly})_{2} \mathrm{Cl}$, $\mathrm{Mn}(\text { gly })_{2} \mathrm{Br}, \mathrm{Mn}(\text { gly })_{2} \mathrm{~N}_{3}$ and $\mathrm{Mn}(\text { gly })_{2} \mathrm{NCS}$ have been synthesized to see if the catalytic properties of these novel mixed ligand complexes towards the decolourization of dye in presence of $\mathrm{H}_{2} \mathrm{O}_{2}$ is enhanced by the addition of ethylenediamine. 
The purity of these complexes was checked by thin layer chromatography on silica gel glass plates. $A$ single spot for each of the complex indicates that these complexes are pure. All the physical properties of these complexes are summarized in Table 1. The colour is black in all, it indicates that the colour of the complexes is governed by the presence of $\mathrm{Mn}$ (III) ion.

The UV-Vis spectra of the complexes were recorded in dimethyl sulphoxide (DMSO). One of the spectrum for $\mathrm{Mn}(\text { gly })_{2} \mathrm{Cl}(\mathrm{en})$ is shown in Fig. 1 while the $\lambda$ max values for these four complexes are given in Table 2 . The $\lambda$ max and the molar extinction

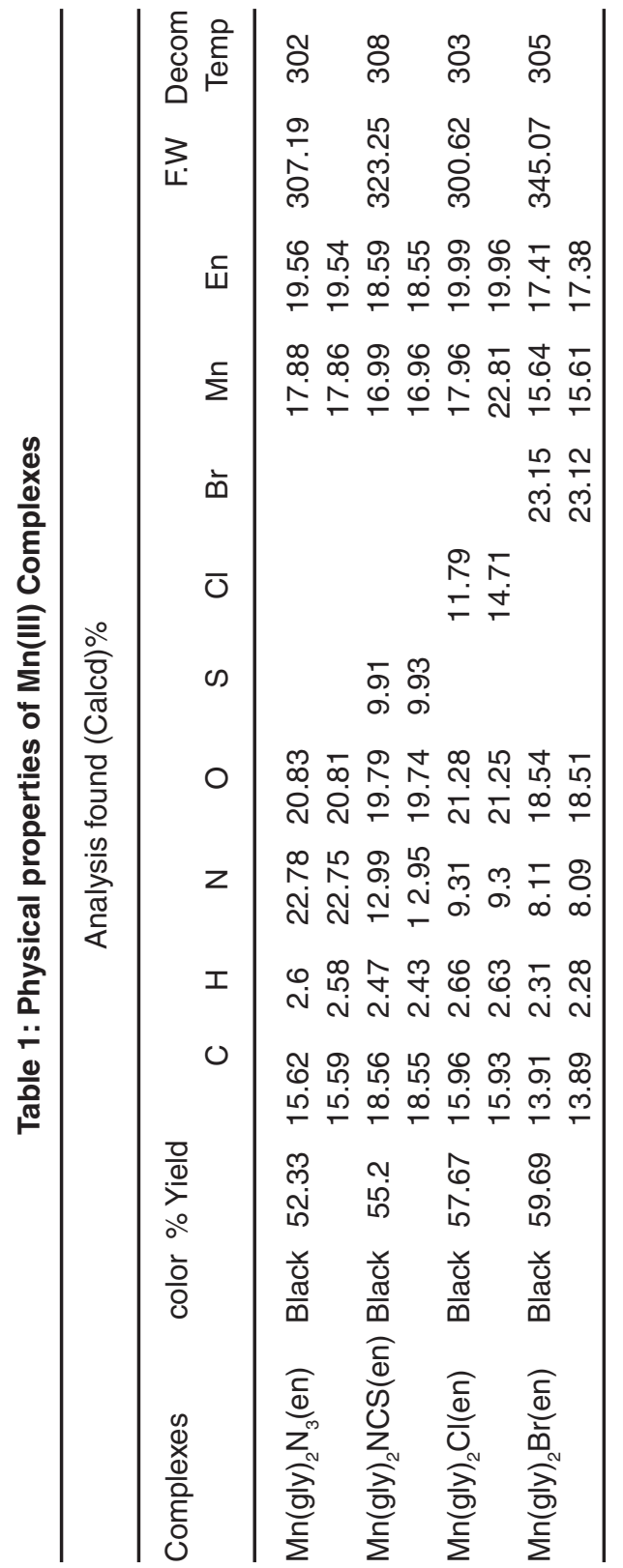

coefficient values for this typical spectrum are $484 \mathrm{~nm}$ and $2.142 \times 103 \mathrm{M}^{-1} \mathrm{~cm}^{-1}$ respectively. The molar extinction coefficient value $\varepsilon_{484}$ for this complex is in the range of spin allowed transition ${ }^{5} \mathrm{~T}_{2 \mathrm{~g}} \rightarrow{ }^{5} \mathrm{Eg}^{29}$. The $\lambda$ max values for all these novel mixed ligand complexes are red shifted in comparison to their parent complexes, thus showing the decrease in the crystal field stabilization energies of these complexes. The crystal field stabilization energies of $\mathrm{Mn}$ (gly) ${ }_{2} \mathrm{Cl}(\mathrm{en}), \mathrm{Mn}\left(\right.$ gly) ${ }_{2} \mathrm{Br}(\mathrm{en}), \mathrm{Mn}(\mathrm{gly}) \mathrm{N}_{3}$ (en) and $\mathrm{Mn}(\mathrm{gly}){ }_{2} \mathrm{NCS}$ (en) have been evaluated as $23674 \mathrm{~cm}^{-1}, 23466 \mathrm{~cm}^{-1}, 23854 \mathrm{~cm}^{-1}$ and $2333 \mathrm{~cm}^{1}$ respectively whereas the crystal field stabilization energies of $\mathrm{Mn}$ (gly) ${ }_{2} \mathrm{Cl}, \mathrm{Mn}\left(\right.$ gly) ${ }_{2} \mathrm{Br}, \mathrm{Mn}$ (gly) ${ }_{2} \mathrm{~N}_{3}$ and $\mathrm{Mn}(\mathrm{gly})_{2} \mathrm{NCS}$ are $29,069 \mathrm{~cm}^{-1}, 28409 \mathrm{~cm}^{-1}$, $25201 \mathrm{~cm}^{-1}$ and $27173 \mathrm{~cm}^{-1}$ respectively ${ }^{26}$. In this way the ethylenediamine complexes are relatively less stable than their parent complexes. The ligand field parameters such as $10 \mathrm{Dq}, \mathrm{B}$ and $\beta$ have also been calculated for these ethylendiamine $\mathrm{Mn}$ (III) complexes and are summarized in Table 2. The values of Racah interelectronic repulsion parameter $(\mathrm{B})$ are below the free ion value for $\mathrm{Mn}(\mathrm{III})$ ion $\left(1140 \mathrm{~cm}^{-1}\right)^{30}$ it confirms the covalent nature of metal ligand bonds present in all four complexes while the covalency factor $\beta$ is varying in the range of 0.75-0.77.

Table 2: $\lambda$ max values and Ligand Field Parameter of all these mixed ligand complexes

\begin{tabular}{|c|c|c|c|c|}
\hline Complexes & $\lambda \max$ & 10Dq $\left(\mathrm{Cm}^{-1}\right)$ & $\mathrm{B}\left(\mathrm{Cm}^{-1}\right)$ & $\beta$ \\
\hline $\mathrm{Mn}(\text { gly })_{2} \mathrm{~N}_{3}(\mathrm{en})$ & 482 & 23,854 & 883 & 0.77 \\
\hline $\mathrm{Mn}\left(\right.$ gly) ${ }_{2} \mathrm{NCS}$ (en) & 488 & 23,320 & 863 & 0.75 \\
\hline $\mathrm{Mn}\left(\right.$ gly) ${ }_{2} \mathrm{Br}(\mathrm{en})$ & 486 & 23,496 & 870 & 0.76 \\
\hline $\mathrm{Mn}(\text { gly })_{2} \mathrm{Cl}(\mathrm{en})$ & 484 & 23,674 & 876 & 0.76 \\
\hline
\end{tabular}

The results of the FT-IR spectra of the complexes [ $\left.\left.\mathrm{Mn}^{(\mathrm{III})}(\mathrm{gly})_{2} \mathrm{Cl}(\mathrm{en})\right], \mathrm{Mn}^{\text {(III) }}(\mathrm{gly})_{2} \mathrm{Br}(\mathrm{en})\right]$, $\left[\mathrm{Mn}^{(\mathrm{III})}(\mathrm{gly})_{2} \mathrm{NCS}(\mathrm{en})\right]$, and $\left[\mathrm{Mn}^{(\mathrm{III})}(\mathrm{gly})_{2} \mathrm{~N}_{3}(\mathrm{en})\right]$ are summarized in Table 3. All the four complexes show a strong peak around $3400 \mathrm{~cm}^{-1}$ due to $\mathrm{NH}_{2}$ group coordinated to $\mathrm{Mn}(\mathrm{III})$. The Strong peak at 3583 $\mathrm{cm}^{-1}$ is due to free amino group that is possible only when en acts as a monodentate ligand instead of bidentate or bridging ligand. These findings indicate that these mixed ligand complexes of $\mathrm{Mn}(\mathrm{III})$ are monomeric in nature and not dimeric as reported in the earlier literature for a few cases ${ }^{31}$. In the case of azidobis(glycinato)manganese(III)(en) one significant band is observed at $2040 \mathrm{~cm}^{-1}$ showing the coordination of azido group with the $\mathrm{Mn}(\mathrm{III})$. The spectrum of thiocynatobis(glycinato)manganese(III) (en) shows a band characteristic for coordinated NCS group $v(\mathrm{Mn}-\mathrm{N})$ at $2090 \mathrm{~cm}^{-1}$ indicating the coordination of thiocyanato group to the metal through nitrogen donar atom ${ }^{32}$. These complexes are monomeric instead of dimeric this is also supported by the mass spectrophotometric studies also. One of typical mass spectrum for $\left[\mathrm{Mn}^{(\mathrm{III})}(\mathrm{gly}) \mathrm{N}_{2} \mathrm{~N}_{3}\right.$ (en)] is shown in Fig. 2 it shows the presence of molecular ion peak at $\mathrm{m} / \mathrm{z}=307$ that corresponds to the monomeric species present in this mixed ligand complex. 


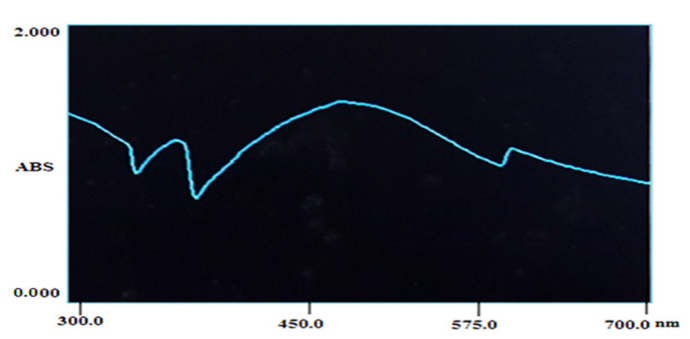

Fig. 1. UV-Visible spectra of chlorobis(glycinato)Mn(III) ethylenediamine $\left[\mathrm{Mn}(\mathrm{gly})_{2} \mathrm{Cl}(\mathrm{en})\right]$ complex

The magnetic moment values for all these manganese(III) complexes have been found in the range of 4.20-4.90 BM at room temperature. It confirms the presence of four unpaired electrons and a highspin $\mathrm{d}^{4}$ system in all the four novel complexes ${ }^{33,34}$. On the basis of all the above studies distorted octahedral structure has been proposed for all the novel mixed ligand complexes and it is given as in Figure 4.

Now a days oxidation and removal of synthetic dyes from the environment has become one of the important research areas to control environmental pollution. These novel complexes have been tested for their ability to decolourize Methyl red in presence of $\mathrm{H}_{2} \mathrm{O}_{2}$. The UV spectrum of decolourization reaction of Methyl Red using the initial $\left[\mathrm{Mn}(\mathrm{gly})_{3}\right]$ is shown in Fig. 3 here Fig. 3 (a) is the spectrum of $0.2 \%$ methyl red in $14.63 \% \mathrm{H}_{2} \mathrm{O}_{2}$ in milliQ water and Fig. 3 (b) is the spectrum of the dye decolourized in presence of $\left[\mathrm{Mn}(\mathrm{gly})_{3}\right]$ complex. In separate experiments, relative efficiencies of $\left[\mathrm{Mn}(\mathrm{gly})_{3}\right],\left[\mathrm{Mn}(\mathrm{gly})_{2} \mathrm{Cl}\right]$ and $\left[\mathrm{Mn}(\mathrm{gly})_{2} \mathrm{Cl}(\mathrm{en})\right]$ have been tested towards their ability to decolourize Methyl Red dye. The composition of reaction solution and time required for complete decolourization of the dye are given in Table 4. The order of efficiency of decolourization for methyl red in presence of these complexes can be given as $\left[\mathrm{Mn}^{(\text {III) }}(\mathrm{gly})_{2} \mathrm{Cl}(\mathrm{en})\right]>\left[\mathrm{Mn}(\mathrm{gly})_{3}\right]\left[\mathrm{Mn}^{(\text {III) }}(\mathrm{gly})_{2} \mathrm{Cl}\right]$. The time required for the complete decoulourization of $0.24 \%$ Methyl Red in the presence of $14.63 \% \mathrm{H}_{2} \mathrm{O}_{2}$ in case of $\mathrm{Mn}(\mathrm{gly})_{2} \mathrm{Cl}$ (en) complex is only five second while in case of $\mathrm{Mn}$ (gly) $)_{3}$ it is 10 second and in case of $\mathrm{Mn}(\mathrm{gly})_{2} \mathrm{Cl}$ it is 90 second. These complexes have been used for three cycles of catalysis without any apparent change, Complexes are reusable efficient heterogeneous catalysts for dye decolourization and in this way may be used on the industrial scale for the removal of environmental pollution caused by organic dyes.

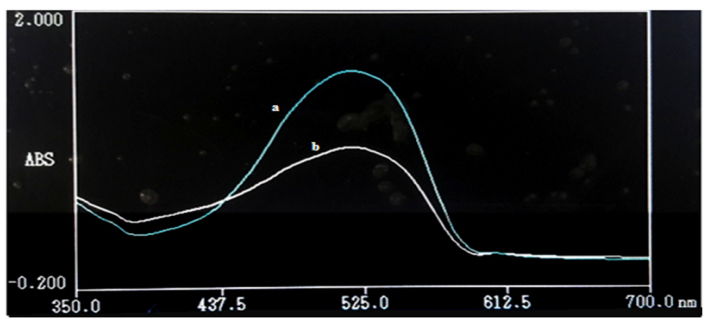

Fig. 3. Decolorizationof methyl red in presence of $\mathrm{H}_{2} \mathrm{O}_{2}$ by the glycinato complex. (a) Spectrum of $0.2 \%$ methyl red in $14.62 \%$ $\mathrm{H}_{2} \mathrm{O}_{2}$ in milliQ water, (b) Spectrum of decolourized $0.2 \%$ methyl red by $\mathrm{Mn}(\mathrm{gly})_{3}$ complex in $14.62 \% \mathrm{H}_{2} \mathrm{O}_{2}$ in milliQ water

Table 3: FT-IR spectra of all these complexes

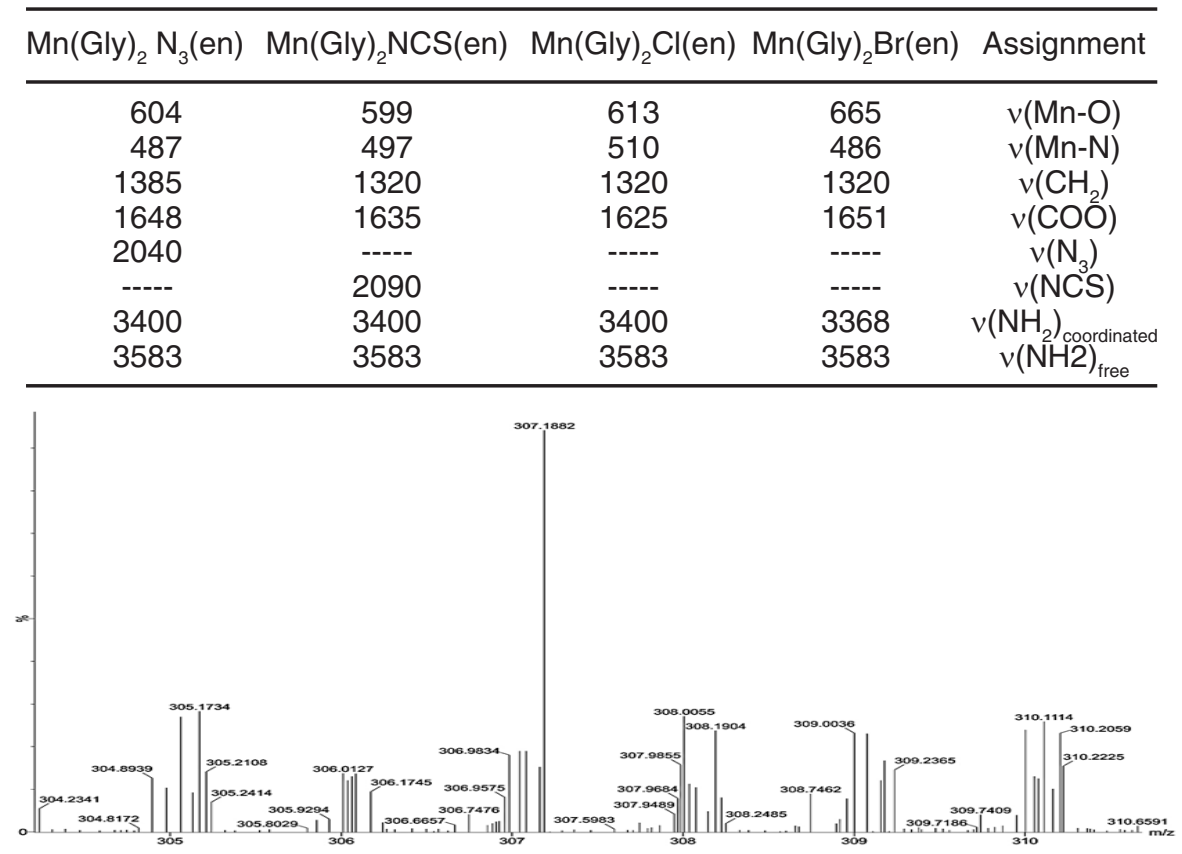

Fig. 2. DART Mass spectra of azidobis(glycinato)Mn(III)ethylenediamine $\left[\mathrm{Mn}(\mathrm{gly})_{2} \mathrm{~N}_{3}(\mathrm{en})\right]$ complex 


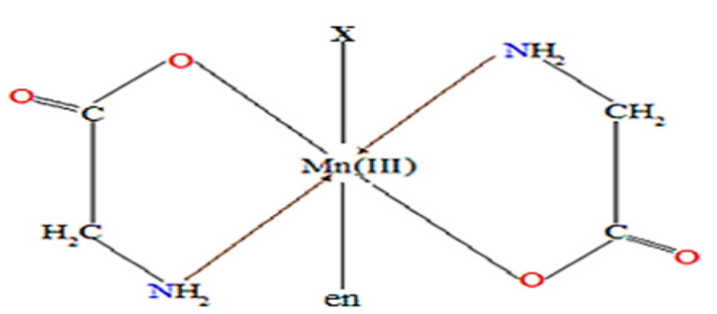

Fig. 4. Structure for all these synthesized complexes, $\left[\mathrm{Mn}(\mathrm{gly})_{2} \mathrm{X}(\mathrm{en})\right]$ Where $\mathrm{X}=\mathrm{Cl}^{-}, \mathrm{Br}^{-}, \mathrm{N}_{3}{ }^{-}, \mathrm{NCS}^{-}$

Table 4: The results of decolourization of methyl red by the complexes

\begin{tabular}{cccc}
\hline S.No. & Complexes & \multicolumn{2}{c}{ Quantity } \\
\hline 1. & $\mathrm{Mn}(\mathrm{gly})_{3}$ & $0.5 \mathrm{mg}$ & $10 \mathrm{sec}$ \\
2. & $\mathrm{Mn}(\mathrm{gly})_{2} \mathrm{Cl}$ & $0.5 \mathrm{mg}$ & $90 \mathrm{sec}$ \\
3. & $\mathrm{Mn}(\mathrm{gly})_{2} \mathrm{Cl}(\mathrm{en})$ & $0.5 \mathrm{mg}$ & $5 \mathrm{sec}$ \\
\hline
\end{tabular}

\section{CONCLUSION}

Four novel complexes [ $\left.\mathrm{Mn}^{(\text {(III) }}(\mathrm{gly})_{2} \mathrm{Cl}(\mathrm{en})\right]$, $\left[\mathrm{Mn}^{(I I I)}(\text { gly })_{2} \mathrm{Br}(\mathrm{en})\right],\left[\mathrm{Mn}^{(I I I)}(\mathrm{gly})_{2} \mathrm{NCS}(\mathrm{en})\right]$, and
$\left[\mathrm{Mn}^{(\mathrm{III})}(\mathrm{gly})_{2} \mathrm{~N}_{3}(\mathrm{en})\right]$ have been synthesized and characterized by UV-Visible, FT-IR, Mass spectrophotometry and magnetic susceptibility measurements. Their tentative structure has been proposed to be octahedral. These ethylenediamine mixed ligand complexes of $\mathrm{Mn}(\mathrm{III})$ are better reusable heterogeneous catalysts for the decolourization of Methyl Red in presence of $\mathrm{H}_{2} \mathrm{O}_{2}$

\section{ACKNOWLEDGMENT}

The authors are thankful to CSIR New Delhi for the financial support through the grant no. 02(0261)/16/EMR II dated 28/04/16. The authors are also thankful to the Head Department of Chemistry, D.D.U. Gorakhpur University, Gorakhpur for administrative support. The authors acknowledge the services rendered by the Sophisticated Analytical Instrument Facility (SAIF), Cochin and Central Drug Research Institute (CDRI), Lucknow for recording FT-IR and DART Mass of the samples and IIT Kanpur (ACMS Department) for magnetic susceptibility measurements.

\section{REFERENCES}

1. Maxwell, J. G.; Peter, T. Coord. Chem. Rev., 1991, 108, 115-161.

2. Jelle, B.; Minze, T. R.; Ronald, H.; Ben, L. F. Inorg Chim Acta., 2002, 337, 75-82.

3. Sumitra, M.; Sanjay, K.; Mandal, S. B.;William, H. A. Chem. Rev., 2004, 104, 3981-4026.

4. Suzana, C.; Caslav L.; Goran, N.; Jakov S.; Milos. R.; Miladin, G. M. Sensors., 2006, 6, 1708- 1720.

5. Donald, J. D.; Eric B. F. Inorg. Chem., 2007, 46(15), 5967-5978.

6. Qian, P.; Shi, Z.; Hao, S.; Nian, Li.;Yu-Ping, T; Wei, Li.; Hao T.; Wei- Z.; Min-Zhe S.; Jin, A. D. Curr. Organ. Chem., 2013, 17, 2936-2970.

7. Chetan, K.; Modi, P.; M. Trivedi. J. Coordi. Chem., 2014, 67(22), 3678-3688.

8. Mojtaba, B.; Mohammad, M, H.; Firouz. M. J. Coord. Chem., 2013. 66(17), 3025-3036.

9. Saeed, R.; Elaheh, B.; Saeed, Z. J. Coord. Chem., 2016, 638-649.

10. Manuel, R. B.; Rocio, C.; Fernandez, G.; M, Isabel.;Ana, M.; G, N.; Gustavo, G. R.; Marcelino, M.; Laura, R. S. J. Chem., 2017, 1-10.

11. Garcia, A.M.; Moreno, V.; Delgado, SX.; Ramirez, AE.; Vargas, LA.; Vicente, MA.; Gil, A. J. Molec. Catal A-Chemical., 2016, 416, 10-19.

12. Dismukes, G. C.; Bioinorganic Catalysis, J. Reedijk, (Ed) First edition, Marcel Dekker Inc, New York., 1993, 317.

13. Faulkner, K. M.; Stevens, R. D.; Fridovich, I. Arch Biochem Biophys., 1994, 2, 341-346.

14. Christian, R.; Goldsmith, A. P.; Cole.T.Daniel;P.S. J. Am. Chem. Soc., 2005, 127(27), 9904-9912.

15. Arpan, D. S.; Biswas, M. D.; Bikash, K. S.; Abhishake, M.; Shyamal, K. S.; Mahammad A. RSC Advances., 2015, 5, 23855-23864.

16. Hossein, A. ; Gus, J. P., Inorg. Chem., 1982, 21, 3903-3907.
17. Shalaby, M. S.; Abdallah. H., Front. Chem. Sci. Eng., 2013, 7(3), 329-337.

18. Iffet, S.; Necla, G.;Turgut G., Synth. React. Inorg. Met.-Org. Chem., 2001, 31(7), 1175-1187.

19. Altan, Guvenc.; Karabacakoglu, B., Turk J Chem., 2000, 24, 101-108.

20. Bhagwan, S. G.: Asha, L. D.; Ranjna, D. Transition. Met. Ċhem., 1988, 13, 351-355.

21. Laurence, J. B.; Victor, W. Day.; Inorganic Chemistry., 1977, 16, 1360-1667.

22. Sudha, Y.; Şhashi.' L. B. J.Coordi.Chem., 2011, 64, 3950-3959.

23. Shashi, L. B.; Sudha, Y. J.Coord. Chem., 2012 65, 3492-3501.

24. Niharika, A.; Sudha, Y. J. Coord. Chem., 2018

25. (accepted). Sudha. Y. J. Coord. Chem., 2018. (accepted).

26. Deepika, J; Sudha, Y., Inorg. Chim. Acta., (communicated).

27. Jelle, B.; Minze T.; Ronald, H.; Ben, L. F. Inorg. Chim. Acta., 2002, 337, 75-82.

28. Manabendra, N. B.; Mihir, K. C.; Darlando, T K., Dalton Trans., 1982, 669-670.

29. Patel, I. A.; Bharat, T. T., Indian. J. Chem., 1999, 38, 422-433,

30. James, E. H.; Ellen, A. K.; and Richard, L. K. Inorganic Chemistry, Principles of Structure and Reactivity, $4^{\text {th }}$ Edn, Pearson Education, Singapore., 2005, 445.

31. Stults, B. R.; Robert, S. M.; Victor, W. D. Inorg Chem., 1975, 14(4), 722-730.

32. Brahim, B.; Ali. O.; Djouhra, Aggoum.; Ramiro, R. R.; Yasmina, O.; Emilia, M. Res. Chem. Intermed., 2016, 42(5), 4839-4858.

33. Behere, D. V.; Samaresh, M. Inorg. Chem., 1980, 19, 992-995.

34. Fleischer, E. B.; Palmer, J. M.; Srivastava, T. S.; Chatterjee, A. J. Am. Chem. Soc., 1971, 93, 3162-3167. 